\title{
Environmental pollutants and type 2 diabetes: a review of mechanisms that can disrupt beta cell function
}

\author{
T. L. M. Hectors $\cdot$ C. Vanparys $\cdot$ K. van der Ven • \\ G. A. Martens • P. G. Jorens • L. F. Van Gaal • \\ A. Covaci $\cdot$ W. De Coen $\cdot$ R. Blust
}

Received: 22 October 2010 /Accepted: 7 January 2011 /Published online: 27 March 2011

(C) Springer-Verlag 2011

\begin{abstract}
The prevalence of diabetes mellitus is currently at epidemic proportions and it is estimated that it will increase even further over the next decades. Although genetic predisposition and lifestyle choices are commonly accepted reasons for the occurrence of type 2 diabetes, it has recently been suggested that environmental pollutants are additional risk factors for diabetes development and this review aims to give an overview of the current evidence for this. More specifically, because of the crucial role of pancreatic beta cells in the development and progression of type 2 diabetes, the present work summarises the known effects of several compounds on beta cell function with reference to mechanistic studies that have elucidated how these compounds interfere with the insulin secreting capacity of beta cells. Oestrogenic
\end{abstract}

Electronic supplementary material The online version of this article (doi:10.1007/s00125-011-2109-5) contains supplementary material, which is available to authorised users.

T. L. M. Hectors $(\bowtie) \cdot$ C. Vanparys $\cdot$ A. Covaci $\cdot$ W. De Coen $\cdot$ R. Blust

Department of Biology, Laboratory of Ecophysiology,

Biochemistry and Toxicology, University of Antwerp,

Groenenborgerlaan 171,

2020 Antwerp, Belgium

e-mail: tine.hectors@ua.ac.be

K. van der Ven

Department of Molecular Genetics,

Applied Molecular Genomics Group,

Flanders Institute for Biotechnology (VIB),

University of Antwerp,

Antwerp, Belgium

G. A. Martens

Diabetes Research Center, Brussels Free University-VUB,

Brussels, Belgium compounds, organophosphorus compounds, persistent organic pollutants and heavy metals are discussed, and a critical reflection on the relevance of the concentrations used in mechanistic studies relative to the levels found in the human population is given. It is clear that some environmental pollutants affect pancreatic beta cell function, as both epidemiological and experimental research is accumulating. This supports the need to develop a solid and structured platform to fully explore the diabetes-inducing potential of pollutants.

Keywords Diabetes mellitus type 2 - Environmental pollutants $\cdot$ Endocrine disruptors $\cdot$ Insulin-secreting cells . Review

P. G. Jorens

Department of Clinical Pharmacology/Clinical Toxicology, Antwerp University Hospital, University of Antwerp, Edegem, Belgium

\section{F. Van Gaal}

Department of Diabetology, Metabolism and Clinical Nutrition, Antwerp University Hospital, University of Antwerp, Edegem, Belgium
A. Covaci
Toxicological Center, University of Antwerp,
Antwerp, Belgium 


\begin{tabular}{|c|c|}
\hline \multicolumn{2}{|l|}{ Abbreviations } \\
\hline$\left[\mathrm{Ca}^{2+}\right]_{\mathrm{i}}$ & Intracellular free calcium concentration \\
\hline CREB & cAMP response element-binding protein \\
\hline $\mathrm{E}_{2}$ & $17 \beta$-Oestradiol \\
\hline EDC & Endocrine-disrupting compound \\
\hline EPA & Environmental Protection Agency \\
\hline ER & Oestrogen receptor \\
\hline ERE & Oestrogen responsive element \\
\hline FAO & Food and Agriculture Organization \\
\hline GSIS & Glucose-stimulated insulin secretion \\
\hline JMPR & $\begin{array}{l}\text { Joint FAO/WHO Meeting of Pesticide } \\
\text { Residues }\end{array}$ \\
\hline $\mathrm{K}_{\mathrm{ATP}}{ }^{+}$channel & ADP/ATP-sensitive potassium channel \\
\hline LOAEL & Lowest observed adverse effect level \\
\hline ncmER & $\begin{array}{l}\text { Non-classical membrane oestrogen } \\
\text { receptor }\end{array}$ \\
\hline NOAEL & No observed adverse effect level \\
\hline NOS & Nitric oxide synthase \\
\hline $\mathrm{OPC}$ & Organophosphorus compound \\
\hline PCB & Polychlorinated biphenyl \\
\hline PI3K & Phosphatidylinositol 3-kinase \\
\hline POP & Persistent organic pollutant \\
\hline RfD & Reference dose \\
\hline ROS & Reactive oxygen species \\
\hline TCDD & 2,3,7,8-Tetrachlorodibenzo- $p$-dioxin \\
\hline
\end{tabular}

\section{Introduction}

Changes in human lifestyle and behaviour (e.g. poor diet, lack of exercise), in addition to genetic predisposition and environmental influences, have resulted in a dramatic increase in the incidence of diabetes mellitus worldwide [1]. This global diabetes epidemic is chiefly due to type 2 diabetes as it makes up more than $90 \%$ of all diabetes cases [1].

Type 2 diabetes results from interactions between genetic susceptibility, environmental factors and lifestyle choices. Our understanding of the causes of diabetes, besides genetics, has remained rudimentary, for the most part being limited to the impact of physical inactivity or unhealthy dietary choices [2]. For obesity, which is closely associated with diabetes, a relationship with environmental endocrinedisrupting compounds (EDCs) has been hypothesised based on epidemiological data and in vivo rodent studies. In this scenario the chemicals that disrupt lipid regulation and adipogenesis are defined as obesogens [3]. Although evidence that environmental pollutants might be an additional risk factor for diabetes development is accumulating, a systematic investigation of the possibility that environmental pollutants could be key players in the aetiology of type 2 diabetes [4] has not yet been performed. However, there are strong experimental indications that some pollutants, such as bisphenol A [5] and certain persistent organic pollutants (POPs) [6], affect processes that are related to diabetes development.

While reduced insulin sensitivity and beta cell function are the core pathophysiological defects in type 2 diabetes [7], the relative importance of these abnormalities is still under debate [8]. However, it has recently been acknowledged that beta cell failure is the triggering factor [9] for the progression of pre-diabetic states (impaired glucose tolerance or impaired fasting glucose or both) to full-blown type 2 diabetes. Obviously, investigation of the effects and mechanisms of action of compounds should focus on their roles in both the development and progression of insulin resistance and beta cell dysfunction. To date, with regard to research on environmental causes, insulin resistance has received more attention than beta cell function. However, considering the critical role of pancreatic beta cells in the progression of type 2 diabetes, there is a great need to focus on the impact of chemicals on the function of these cells. This could provide crucial information on normal beta cell function and physiology as well as on compound-specific toxicity.

This review aims to give an overview of the interference of normal beta cell function by environmental pollutants, specifically focusing on proposed mechanisms of disruption of insulin secretion. Furthermore, a critical discussion on the discrepancy between experimental and environmentally relevant exposure concentrations is given, followed by comments on the value of mechanistic studies in human risk assessment.

\section{Insulin secretion}

The role of the pancreatic beta cell is to sense an increase in the concentration of nutrients (notably glucose) in the blood and to deliver an appropriate quantity of insulin into the systemic circulation. This ensures that the sugar is efficiently taken up and stored as glycogen or triglycerides by peripheral tissues (liver, muscle and adipose tissue) [10]. Figure 1 summarises the mechanism of glucose-stimulated insulin secretion (GSIS) as currently understood. After the initial, rapid triggering phase mediated by ADP/ATP-sensitive potassium channels $\left(\mathrm{K}_{\text {ATP }}{ }^{+}\right.$channels; Fig. 1, see label A), additional signals are necessary to produce the sustained secretion elicited by glucose [11] via a $\mathrm{K}_{\text {ATP }}{ }^{+}$channel-independent pathway (reviewed in [10-12]). Furthermore, to sustain the insulin secretion capacity and the glucose responsiveness of beta cells, glucose also elicits effects at the translational (Fig. 1, see label D) [13] and transcriptional level (Fig. 1, see label C) $[14,15]$. 


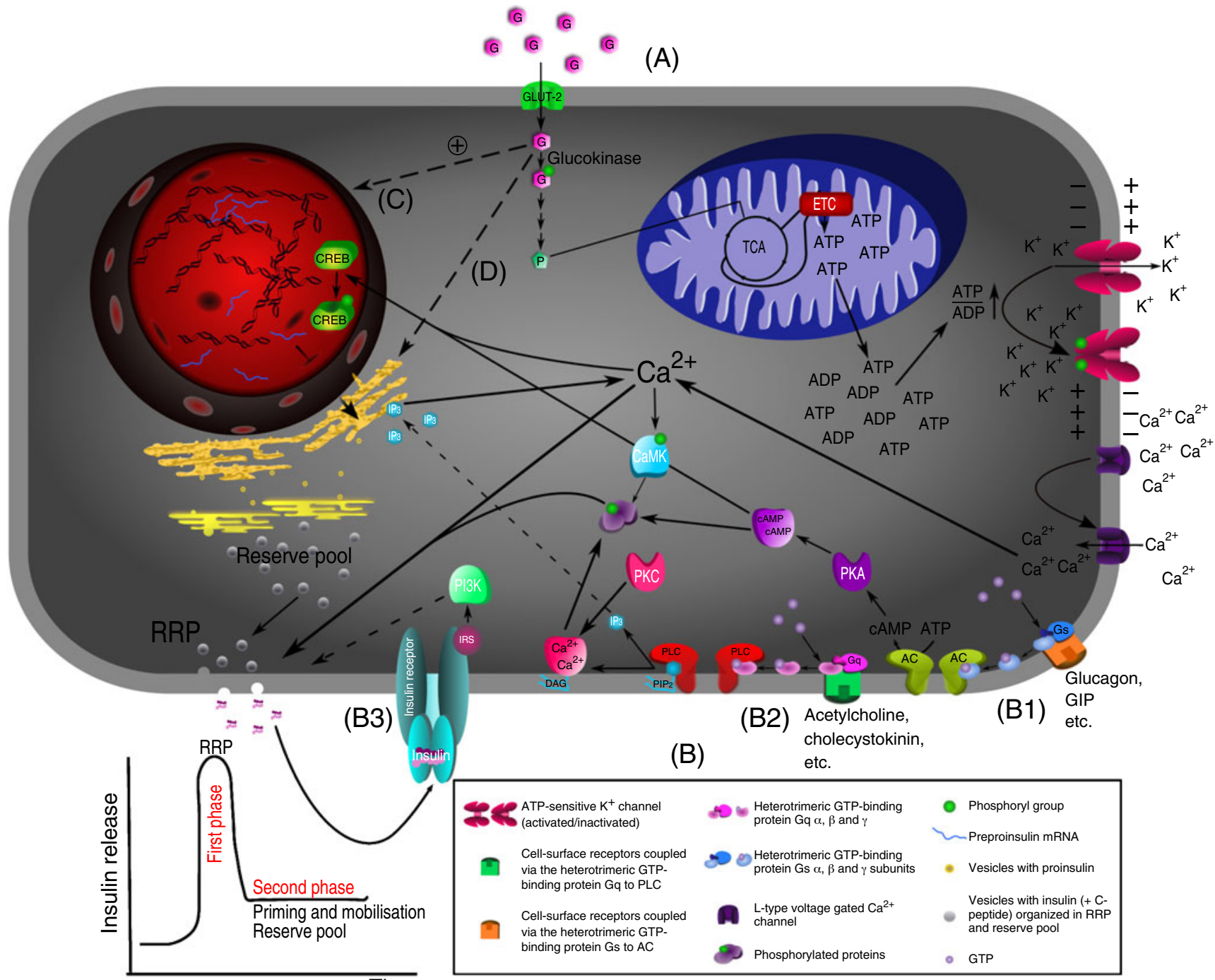

Time

Fig. 1 Mechanism of insulin secretion. (A) The classical pathway of GSIS. Once glucose is taken up via GLUT-2, it is phosphorylated to glucose 6-phosphate by the high $K_{\mathrm{m}}$ glucokinase, followed by entry into the glycolytic pathway and mitochondrial oxidation. Mitochondrial ATP production promotes the closure of $\mathrm{K}_{\text {ATP }}{ }^{+}$channels, and as a consequence the depolarisation of the plasma membrane. In turn, the decrease in voltage leads to the opening of voltage-sensitive $\mathrm{Ca}^{2+}$ channels and an influx of $\mathrm{Ca}^{2+}$ ions, increasing $\left[\mathrm{Ca}^{2+}\right]_{\mathrm{i}}$. High $\left[\mathrm{Ca}^{2+}\right]_{\mathrm{i}}$ induces activation of CaMK, resulting in phosphorylation of enzymes and proteins important in insulin secretion. The combination of high $\left[\mathrm{Ca}^{2+}\right]_{\mathrm{i}}$ and activation of potentiating proteins triggers exocytosis. After this initial, rapid triggering phase (first phase), the amplification or $\mathrm{K}_{\mathrm{ATP}}{ }^{+}$channel-independent pathway (second phase) sustains secretion elicited by glucose. To sustain insulin secretion and adequate nutrient sensing, glucose also directly influences transcription $(\mathrm{C})$ and translation (D). (B) Possible pathways of both nutrient and nonnutrient secretagogues that are thought to be involved in insulin secretion. (B1) Glucagon, GIP, etc. bind to cell surface receptors that are coupled to AC via the heterotrimeric GTP-binding protein $\mathrm{G}_{\mathrm{s}}$. Receptor binding activates AC, which produces cAMP from ATP. cAMP binds to PKA, resulting in phosphorylation and activation of insulin secretion promoting proteins. Additionally, PKA, together with $\mathrm{Ca}^{2+}$, activates the CREB transcription factor which induces, amongst others, insulin gene transcription. (B2) The neurotransmitter acetylcholine and the gastrointestinal hormone cholecystokinin affect insulin secretion by binding to receptors associated with the heterotrimeric GTP-binding protein $\mathrm{G}_{\mathrm{q}}$ coupled to PLC. Activation of PLC leads to hydrolysis of $\mathrm{PIP}_{2}$ with concordant production of $\mathrm{IP}_{3}$ and DAG. $\mathrm{IP}_{3}$ stimulates release of $\mathrm{Ca}^{2+}$ from the endoplasmic reticulum, activates CaMK and thereby stimulates insulin secretion. The plasma membrane-bound DAG activates PKC, which translocates from the plasma membrane to the cytosol and phosphorylates a number of proteins that facilitate insulin secretion. (B3) The autocrine effect of insulin on insulin secretion. Although debate is ongoing as to whether insulin secretion is negatively or positively affected by insulin, it is thought to be mediated by PI3K. AC, adenylate cyclase; CaMK, $\mathrm{Ca}^{2+}$ / Calmodulin-dependent protein kinase II; DAG, diacylglycerol; ETC, electron transport chain; G, glucose; GIP, glucose-dependent insulinotropic polypeptide; $\mathrm{IP}_{3}$, inositol triphosphate; $\mathrm{P}$, pyruvate; $\mathrm{PIP}_{2}$, phosphatidylinositol bisphosphate; PK, protein kinase; PLC, phospholipase C; RRP, ready releasable pool; TCA, tricarboxylic acid cycle 
Besides glucose, other nutrient and non-nutrient secretagogues actively regulate beta cell function, presumably by binding to their respective membrane-bound receptors followed by activation of intracellular signal transduction pathways (Fig. 1, see labels B1, B2 and B3) [12].

At the whole body level, insulin secretory capacity depends not only on the adequate functioning of the individual beta cells, but also on the total number of beta cells, which is physiologically regulated [15]. A multitude of potential hormonal regulators of beta cell growth and proliferation have been described, e.g. gastrin, epidermal growth factor, incretins, growth hormone and insulin(-like) molecules [15]. The G-protein/cAMP/cAMP response element-binding protein (CREB) and insulin/Akt systems are key signalling axes for beta cell survival and proliferation. In turn, glucose also potentiates signalling and regulates gene expression through the latter systems, thereby preserving the ability of beta cells to respond to growth stimulation (reviewed in [14]).

Clearly, normal insulin production depends on a multitude of signal transduction pathways in which many key regulators are present. Adequate glucose sensing not only rapidly regulates insulin synthesis and secretion, but, chronically, is also critical for the maintenance of the glucose-responsive state and the number of beta cells. The large number of regulating factors that can be manipulated relatively easily makes beta cell function a sensitive target for environmental pollutants.

\section{Environmental pollutants and diabetes}

\section{Epidemiological evidence}

The most convincing evidence for a relationship between diabetes and environmental pollutants comes from accidental or occupational exposures to high levels of these compounds [6]. One of the most striking examples is dioxin exposure, which has been positively linked to the elevated prevalence of type 2 diabetes in several populations, e.g. US Air Force veterans from the Vietnam war $[6,16]$, dioxin-exposed individuals following the Seveso accident [17], and populations living nearby [18] or working at [19] industrial plants producing dioxin-containing pesticides or herbicides. Apart from dioxin, other environmental pollutants have been epidemiologically associated with type 2 diabetes, as summarised in Table 1 [20-39] (reviewed in [6]).

Associations, however, do not necessarily imply a causal link. It is possible that diabetic individuals have a reduced capacity to excrete or metabolise pollutants, or that compounds might actively contribute to disease development and progression. In-depth investigation of the effect of chemicals on the processes leading to the development of diabetes is thus required. As deterioration of beta cell function has a key role in diabetes development, it is unsurprising that the first indication of the possible involvement of environmental pollutants in diabetes onset or progression came from experimental studies investigating mechanisms and effects on insulin secretion.

Experimental evidence: effects on beta cell function

\section{Oestrogens and xenoestrogens}

Although long considered a plain sex hormone, it is now acknowledged that $17 \beta$-oestradiol $\left(\mathrm{E}_{2}\right)$ plays an important role in the function of the cardiovascular, musculoskeletal, immune and central nervous systems [40]. Moreover, $\mathrm{E}_{2}$ has recently been linked to alterations in whole body glucose homeostasis [41]. The most powerful evidence comes from situations where oestrogen levels are outside the physiological range, such as in menopause or pregnancy. Both are considered to be risk factors for diabetes development [42].

With regard to the underlying mechanisms, AlonsoMagdalena et al. [43] showed that oestrogens have direct acute and chronic effects on beta cell function and that different receptors mediate oestrogen action. They demonstrated that chronic $E_{2}$ treatment increases the insulin content of beta cells, thereby enabling the cells to secrete more insulin without altering pancreatic beta cell mass or viability. Experiments using oestrogen receptor (ER) knockout mice (both ER $\alpha$ and $\mathrm{ER} \beta, E s r 1^{-/-}$and $E s r 2^{-/}$) established that direct activation of ER $\alpha$ in vivo and in vitro regulates pancreatic insulin levels [43, 44]. Furthermore, oestrogen-mediated protection of beta cells from injury-stimulated apoptosis also depends on binding to $\mathrm{ER} \alpha[45]$.

Administration of physiological $E_{2}$ concentrations in vivo and in vitro acutely stimulates GSIS [46, 47]. This rapid response is characterised by increased cGMP levels, activating protein kinase $\mathrm{G}$, which closes $\mathrm{K}_{\text {ATP }}{ }^{+}$channels. This, in turn, causes membrane depolarisation, and the resulting increase in the intracellular free calcium concentration $\left(\left[\mathrm{Ca}^{2+}\right]_{\mathrm{i}}\right)$ enhances glucose-induced signals $[46]$ and insulin secretion. Additionally, the $\mathrm{E}_{2}$-stimulated increase in $\left[\mathrm{Ca}^{2+}\right]_{\mathrm{i}}$ rapidly activates the CREB transcription factor, which plays a key function in beta cell survival and division [48]. In this manner, $E_{2}$ initiates a signalling pathway at the plasma membrane that rapidly modifies nuclear function [49]. Initially, Nadal et al. [46] suggested that the rapid responses of beta cells to $E_{2}$ are mediated by a non-classical membrane ER (ncmER), but recently they indicated that acute oestrogen effects are probably the result of binding to an extra-nuclear ER $\beta$ [50]. Although two membrane 


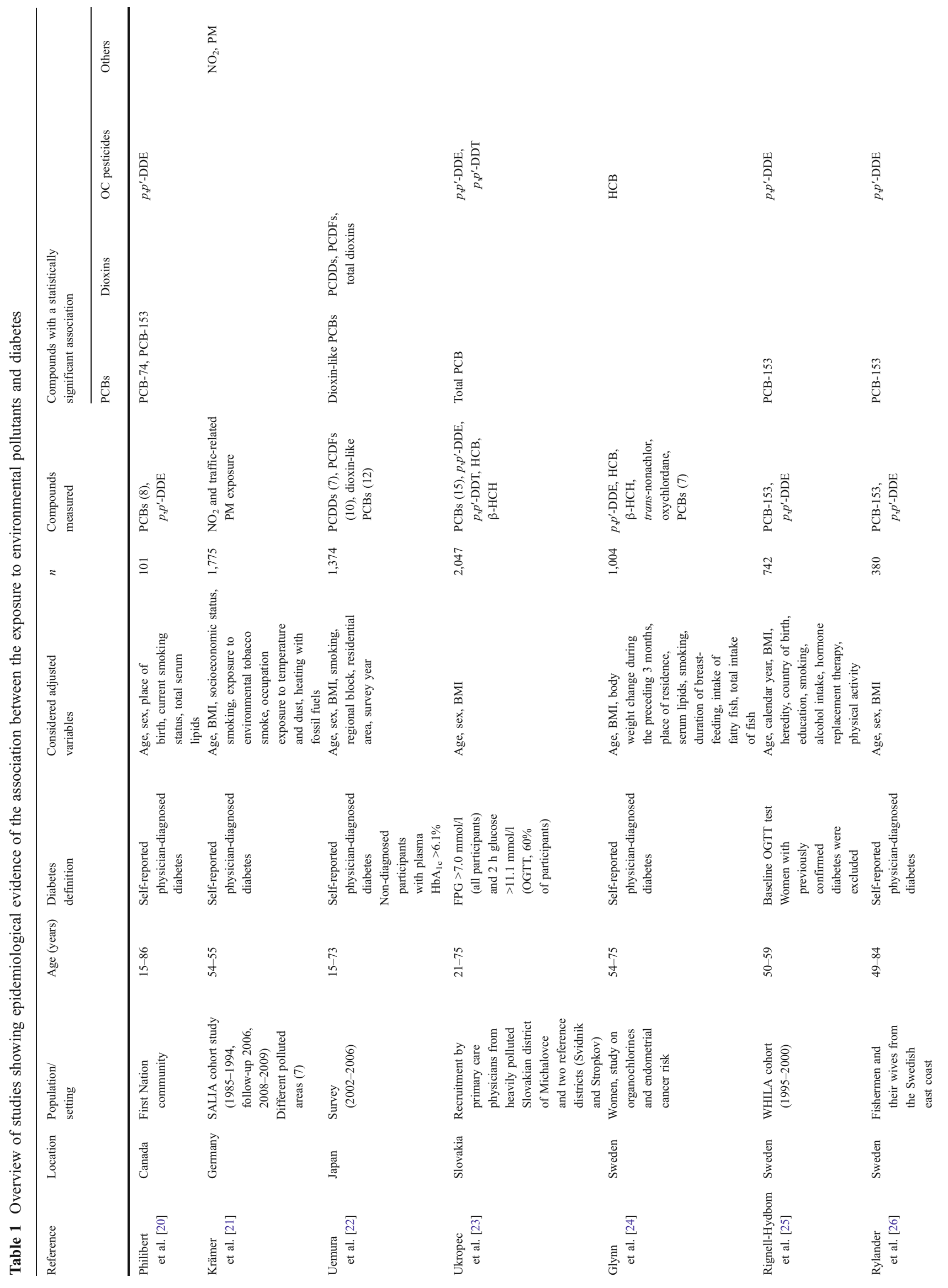




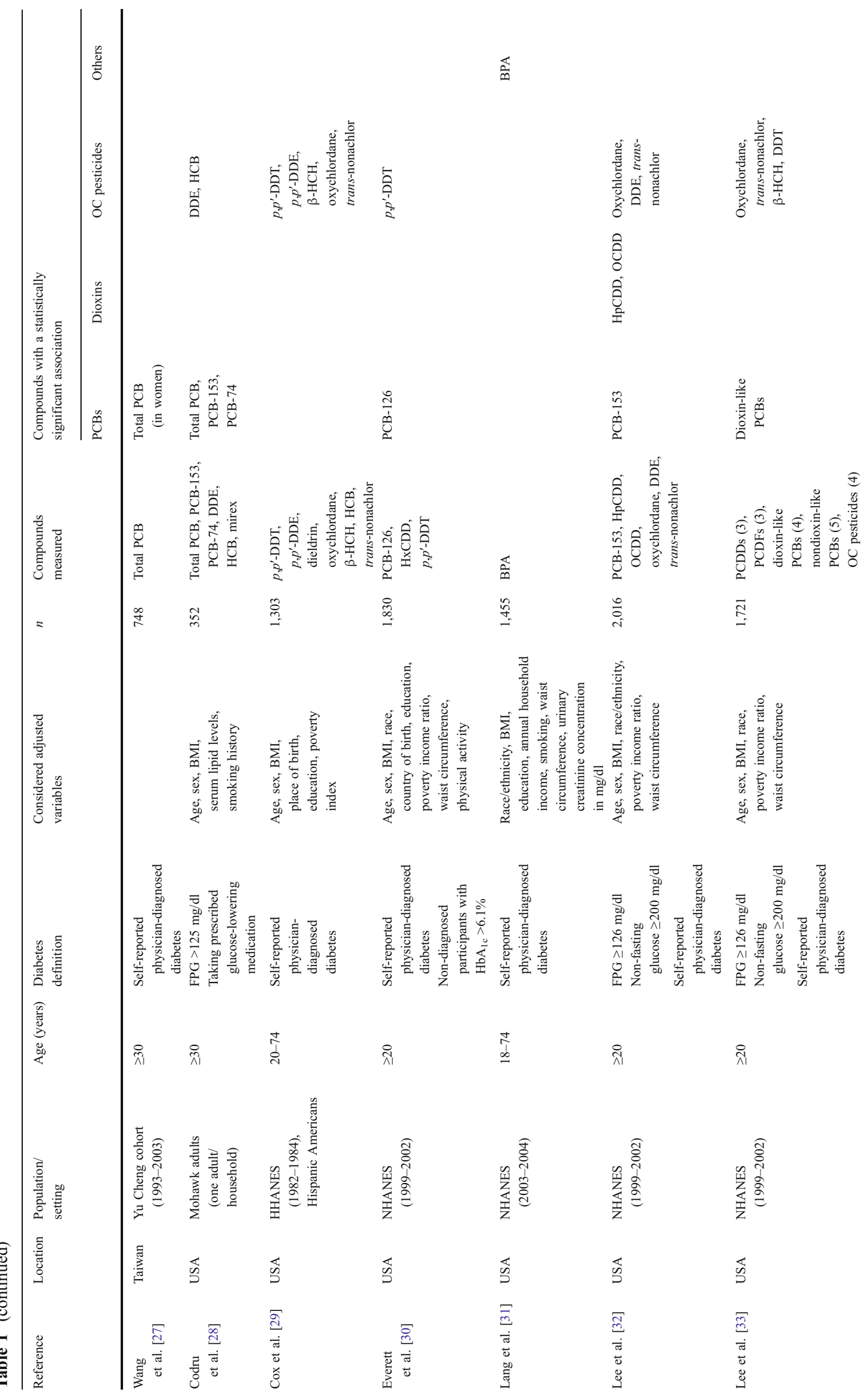




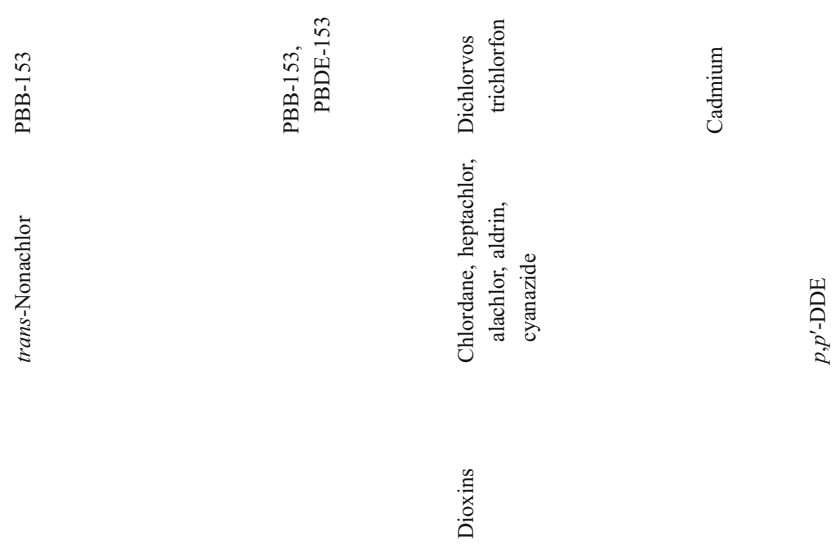

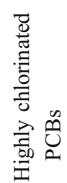

के

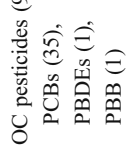
$\stackrel{\infty}{\infty}$

悹兽

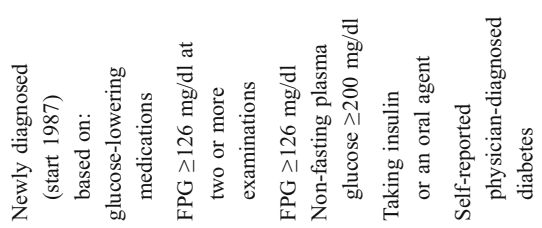

$\underset{\substack{\infty \\ \infty}}{\infty}$

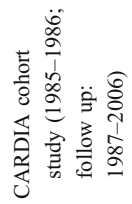

$\overleftrightarrow{s}$

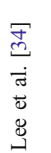

쥬

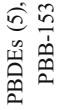

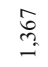
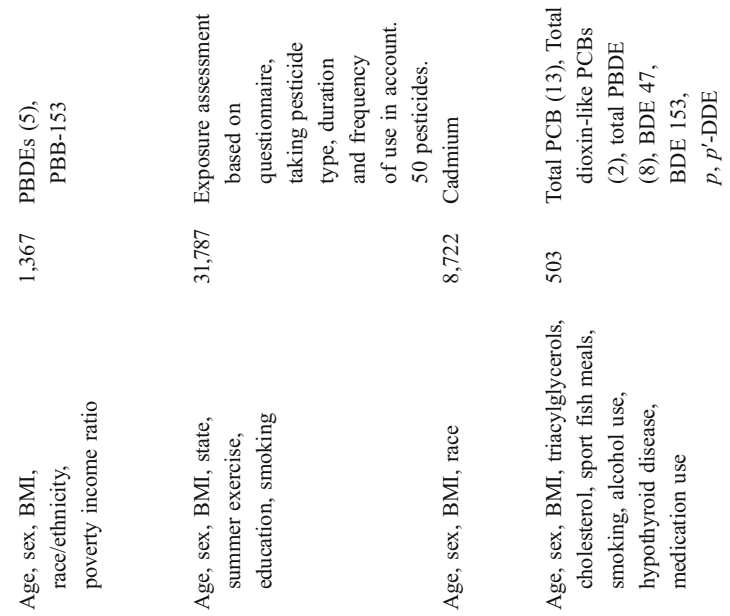

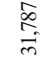
离

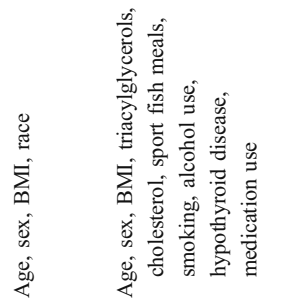

웃
罢

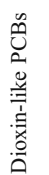

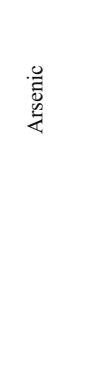

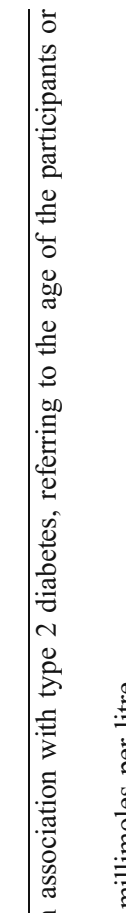

惫

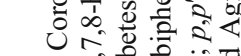

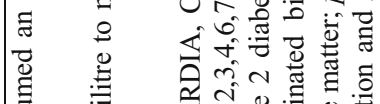

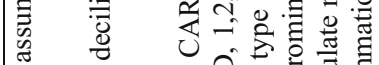

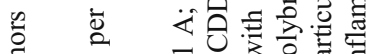

क व

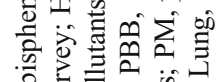

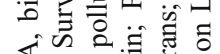

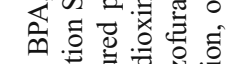

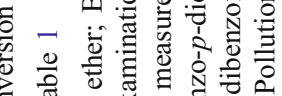

蛋

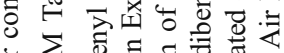

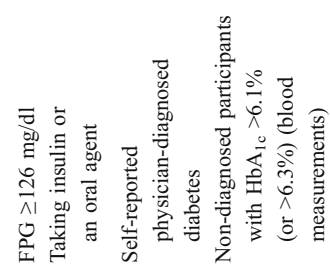

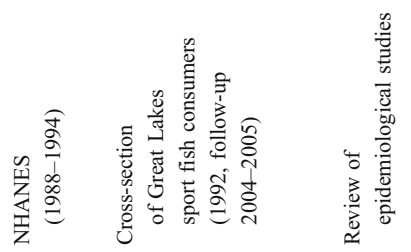

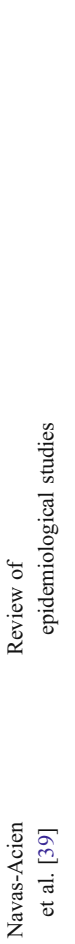

인

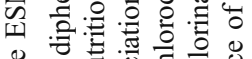

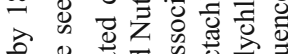

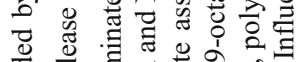

ए : 0

ప

है

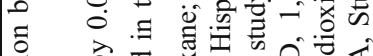

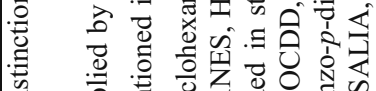

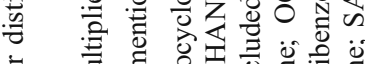

むँ छ

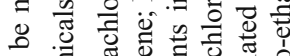

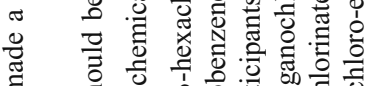

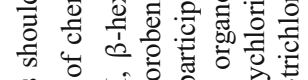

旁

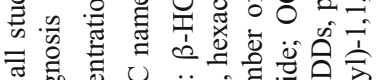

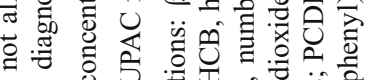

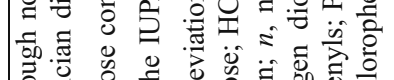

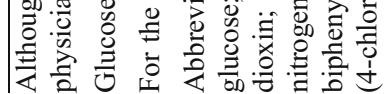

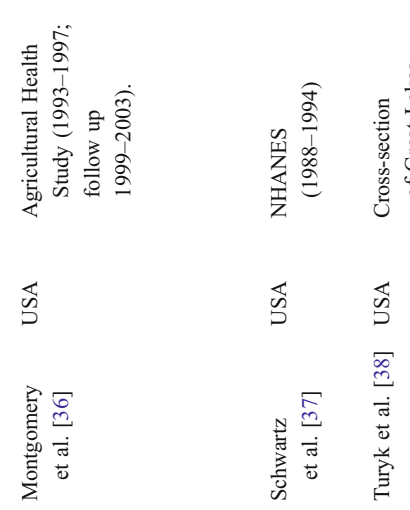

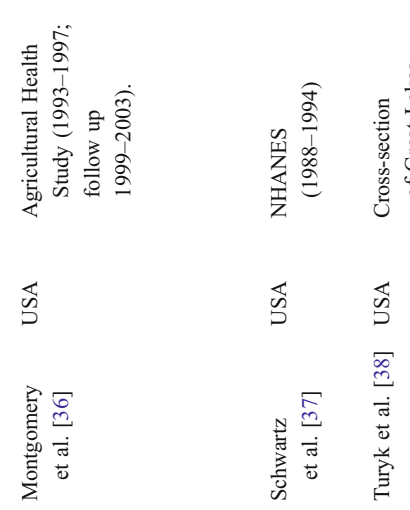


molecules behaving as ncmERs were identified in beta cells, namely the sulfonylurea receptor and the G-proteincoupled oestrogen receptor (also known as GPER or GPR30) [51], they only seem to trigger actions at pharmacological rather than physiological $E_{2}$ concentrations $[44,52,53]$. Thus, the specific contribution of each of these receptors (ER $\alpha, E R \beta, n c m E R)$ in oestrogen-mediated effects on insulin storage and secretion is still not fully known.

Based on these findings, Alonso-Magdalena et al. [43] suggested that environmental oestrogens or xenoestrogens might have a role in the aetiology of type 2 diabetes. They hypothesised that if the positive effect of $E_{2}$ on beta cell function and insulin secretion is taken a step further, prolonged exposure to high oestrogen levels could hyperactivate beta cells. At the whole body level, the ensuing sustained hyperinsulinaemia would be able to induce peripheral insulin resistance and glucose intolerance. This chain of events, commonly referred to as the metabolic syndrome, can explain discrepancies in epidemiological data regarding the beneficial or detrimental effects of oestrogens on glucose homeostasis: a direct stimulatory and protective effect on the beta cell, which, when inappropriately activated, results in insulin secretion not justified by the prevailing glucose concentration. Therefore, the presence of compounds that mimic the actions of $\mathrm{E}_{2}$, socalled xenoestrogens, could profoundly affect normal insulin metabolism and beta cell function. Experiments with bisphenol A provide supporting evidence that environmental oestrogens are strong candidates for the exacerbation and acceleration of the development of type 2 diabetes [47].

Bisphenol A has been shown in multiple independent studies, both in vitro (reviewed in [54]) and in vivo (reviewed in [55]), to act as a xenoestrogen and is registered as an EDC [42] in, among other places, the European Union [56]. Although EDCs were initially linked to effects on the reproductive system and thyroid, nowadays it is recognised that other hormonal and physiological systems may also be fundamentally affected. Supporting evidence comes from the association between EDCs and the metabolic syndrome [42].

Until recently, bisphenol A was considered to be a weak oestrogen because in some bioassays (e.g. uterotrophic assays, in vitro receptor binding assays), it can be up to 100,000-fold less potent than $E_{2}$ [57]. However, bisphenol A is as potent as $E_{2}$ in its effects on beta cell function [47]. In terms of rapid effects on insulin secretion, it has been shown that the dose bisphenol A needed to increase insulin secretion is the same as the dose of $E_{2}$. As for $E_{2}$, both changes in $\left[\mathrm{Ca}^{2+}\right]_{i}[51]$ and CREB phosphorylation and activation [48] are reported. An in vivo experiment showed that bisphenol A rapidly increases plasma insulin and decreases blood glucose values [47]. Because this rapid response is unaffected by the administration of an antioestrogen that blocks the classical ERs, the authors suggested that it is mediated by ncmER [47], although they later declared that these receptors are more likely to trigger their actions at pharmacological $E_{2}$ concentrations and that ER $\beta$ might be the responsible receptor [50].

Long-term treatment with bisphenol A causes the pancreatic insulin content to increase, and this increase is completely abolished when anti-oestrogens are administered [47]. Furthermore, although both $\mathrm{ER} \alpha$ and $\mathrm{ER} \beta$ are present in mouse pancreatic beta cells, ER $\alpha$ is the receptor responsible for the regulation of insulin content by both bisphenol $\mathrm{A}$ and $\mathrm{E}_{2}$ [42]. Since the mouse insulin gene does not contain an oestrogen response element (ERE), the equally effective upregulation of the insulin content by bisphenol $\mathrm{A}$ relative to $\mathrm{E}_{2}$ cannot be explained by the classic pathway of ER-ERE binding [42]. One possible explanation is that bisphenol A could act via ER $\alpha$ through other mechanisms, such as activation of other transcription factors or activation of protein kinases through extra-nuclear $\mathrm{ER} \alpha$.

The findings on the equal potency of bisphenol $\mathrm{A}$ and $\mathrm{E}_{2}$ with respect to effects on pancreatic beta cells are in line with recent developments on the controversial oestrogenicity of bisphenol A [47]. Current opinion holds that bisphenol A is a selective oestrogen receptor modulator and thus its potency and mode of action can vary between different tissues and even between different cell types in the same tissue (reviewed in [57]).

Strengthened by the demonstration of an association between bisphenol A concentrations and diabetes prevalence (Table 1) [31], the above-mentioned studies show that some xenoestrogens are able to alter beta cell function at environmentally relevant doses and thus might be an additional risk factor for diabetes development or progression. However, the modus operandi of other xenoestrogens (e.g. diethylstilbestrol, nonylphenol) remains to be elucidated.

Although our knowledge of how oestrogenic compounds such as bisphenol A, nonylphenol and diethylstilbestrol interfere with insulin homeostasis is far from complete, the disruptive effect of other classes of compounds is much less known. Figure 2 gives an overview of the chemicals for which a mechanism has been proposed and how they might affect insulin secretion.

\section{Organophosphorus compounds}

Organophosphorus compounds (OPCs) are cholinesteraseinhibiting chemicals that are mainly used as pesticides. Inhibition of acetylcholinesterase and the subsequent accumulation of the neurotransmitter acetylcholine at nerve synapses is also the suggested mechanism for OPC toxicity in non-target species $[58,59]$. Many OPCs and their 


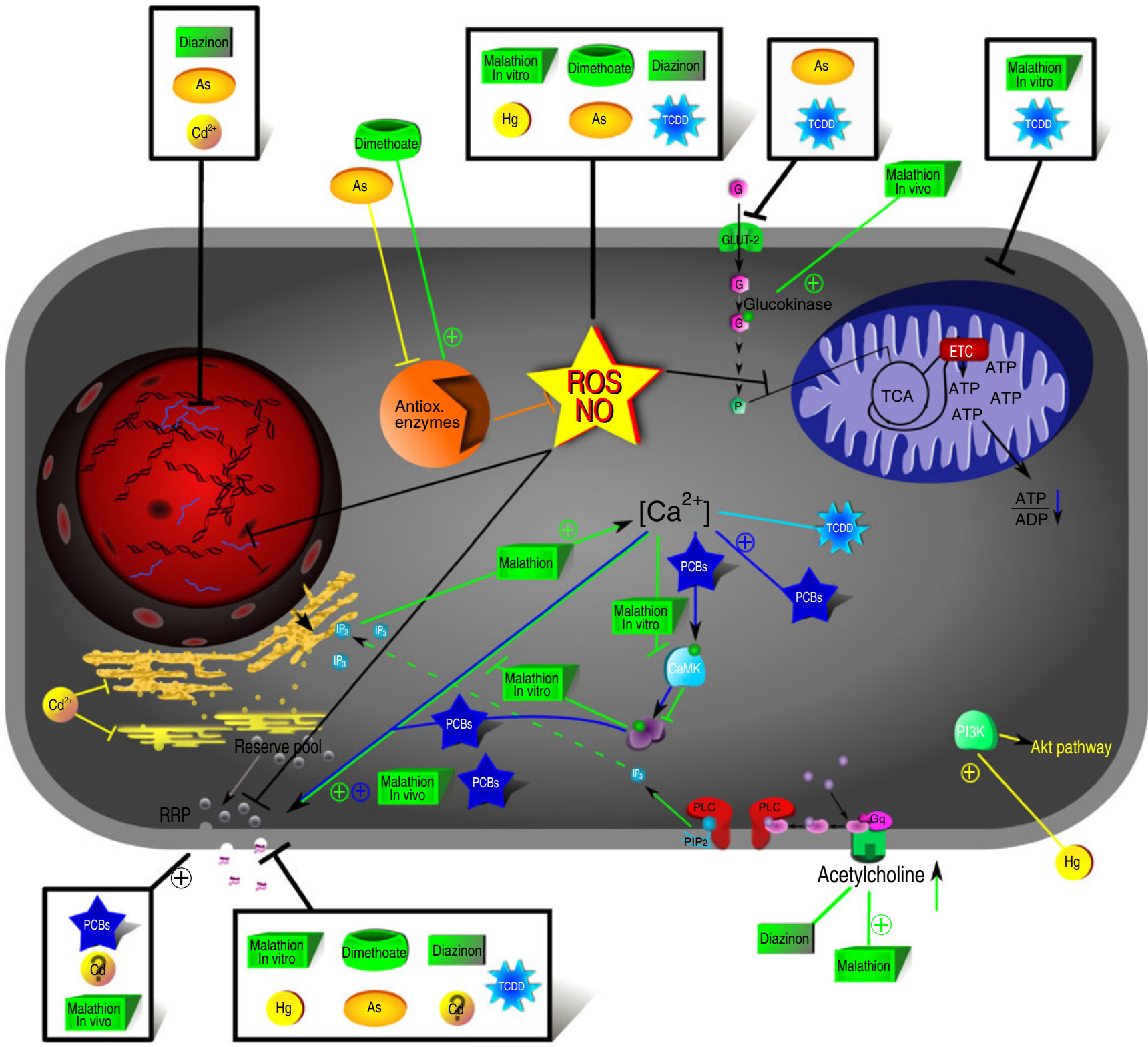

Fig. 2 Disruption of insulin metabolism by environmental pollutants. Current information on the possible mode of action of these chemicals is represented. For key to unlabelled molecules, please see Fig. 1. OPCs are labelled green; POPs, blue; and metals, yellow

metabolites have been shown to be carcinogenic EDCs. They interfere with oestrogen action and thyroid hormones by specifically increasing the expression of oestrogenresponsive genes [60] and preventing thyroid hormonereceptor binding, respectively [61]. The induction of pancreatitis after OPC exposure indicates that OPCs might be able to specifically target pancreatic tissue $[62,63]$. That hyperglycaemia is frequently reported and is considered to be one of the main adverse effects of OPC poisoning in humans and animals is suggestive of specific targeting of the endocrine pancreas by these compounds. The unbalanced glucose homeostasis is probably due to inhibition of acetylcholinesterase at central and peripheral synapses that act in the endocrine regulation of glucose metabolism [64]. Although OPC exposure could possibly be linked to insulin resistance [65], little is known about the impact of OPCs on pancreatic beta cells and the molecular mechanisms supporting this disruption. Malathion is currently one of the most studied OPCs with respect to the mechanisms underlying hyperglycaemia. Remarkably, in vitro and in vivo studies on the effect of malathion on pancreatic beta cells provide contradictory results. In vitro data report a higher insulin content but lower insulin secretion by islets isolated from malathion-treated rats $[65,66]$, whilst reports 
of subchronic exposures to malathion in vivo show a significant increase in plasma insulin and glucose levels [59, 65-67].

In an attempt to disentangle the molecular mechanisms that underlie the malathion-induced increase in insulin secretion in vivo, Pournourmohammadi et al. [65] proposed a role for acetylcholine itself. Through interaction with muscarinic $\mathrm{M}_{3}$ receptors, accumulating acetylcholine is thought to increase GSIS, either through a rise in $\left[\mathrm{Ca}^{2+}\right]_{\mathrm{i}}$ or through affecting the efficacy of $\mathrm{Ca}^{2+}$ in stimulating exocytosis [68], as frequently observed in other tissues [65]. Additionally, the activation of key enzymes involved in insulin secretion, namely glutamate dehydrogenase and glucokinase, has been suggested to explain the malathion-induced increase in insulin secretion (Fig. 2) [67].

Vosough-Ghanbari et al. [66] made further progress in defining the role of $\mathrm{Ca}^{2+}$ in pancreatic malathion toxicity. The authors proposed that a malathion-stimulated increase in $\mathrm{Ca}^{2+}$ levels could cause a functional loss of $\mathrm{Ca}^{2+} /$ calmodulin-dependent protein kinase, a protein associated with insulin secretory granules that is probably involved in exocytosis or insulin granule transport, thereby decreasing $\mathrm{Ca}^{2+}$-induced insulin secretion. However, malathion exerts its cytotoxic effects by induction of apoptosis via a direct effect on the islet's mitochondrial function [65], $\left[\mathrm{Ca}^{2+}\right]_{\mathrm{i}}$ elevation, generation of reactive oxygen species (ROS), and depletion of ATP [66] (Fig. 2). Therefore, the observed $\left[\mathrm{Ca}^{2+}\right]_{\mathrm{i}}$ increase is not a direct indication of insulin secretion, since it is also increased during apoptosis, another known action of malathion in pancreatic cells.

Apart from malathion, diazinon and dimethoate are commonly used OPCs that have been shown to elevate plasma glucose levels while decreasing plasma insulin levels [58, 64]. Both compounds induced oxidative/nitrosative stress in islets of Langerhans, and diazinon produced insulin insufficiency [58]. Diazinon-mediated changes in the cholinergic system could also influence insulin secretion (in a similar manner to malathion; Fig. 2). Other OPCs, including dichlorvos [69] (Table 1) and formothion [70], have previously been reported to have hyperglycaemic effects, but molecular and mechanistic evidence is still missing.

The literature cited above clearly indicates that OPCs have the capacity to disrupt beta cell function and warns of their diabetes-inducing potential, since both hyperinsulinaemia and hyperglycaemia were reported. However, caution should be exercised when seeking to implicate OPCs as one of the main mechanisms of diabetes development because OPC poisoning has also been related to pancreatitis, which is a risk factor for diabetes development.

\section{POPs}

POPs are organic chemicals that are persistent and widely distributed in the environment, have bioaccumulative properties and are toxic to humans and wildlife [71]. Studies have linked POPs to a large spectrum of adverse effects on wildlife species and humans, such as reproductive, developmental, behavioural, neurological, endocrine and immunological alterations. Several POPs have been suggested to be potential EDCs, as they affect fertility, reproduction [72] and thyroid hormone signalling [73] in both wildlife and humans. POPs have also recently been linked to the development of pathologies associated with the metabolic syndrome, including type 2 diabetes, liver and cardiovascular disease (Table 1). In spite of numerous links with disruption of glucose homeostasis (e.g. hyperglycaemia, hyperinsulinaemia, diabetes), these studies are suggestive, though inconclusive, with regard to environmental contaminants as aetiological agents for diabetes and other metabolic diseases.

One of the most investigated POPs related to adverse effects on glucose and lipid metabolism is the extremely toxic 2,3,7,8-tetrachlorodibenzo- $p$-dioxin (TCDD). Several hormone systems in different cell types and tissues and at different developmental stages are being altered by dioxin [74], leading to a complex disruption of multiple endocrine systems. One of the most common symptoms seen in animal species after TCDD exposure is loss of body weight or reduced weight gain [75], commonly referred to as wasting syndrome [76]. Since hypophagia, hyperlipidaemia and hypertriglyceridaemia are observed in TCDD-induced alterations in body weight, the assumption is made that affected animals are unable to utilise the energy-rich nutritional compounds available in their blood. Metabolic derangements related to glucose metabolism have been considered to play a crucial role in the induction of this wasting syndrome [75]. The most important reported effects of TCDD on glucose homeostasis are the reduction of glucose uptake by adipose tissue, liver and pancreas (in vivo as well as in vitro) $[77,78]$, accompanied by decreased insulin production and secretion by the pancreatic beta cells [79]. The biological basis of this decline is still unclear, but TCDD probably affects GSIS by different mechanisms (Fig. 2). First, glucose transport is thought to be reduced as a consequence of TCDD binding to the aryl hydrocarbon receptor [75]. This causes changes in translational and transcriptional mechanisms resulting in diminished GLUT expression, amongst other effects [77, 78, 80]. Furthermore, abolishment of glucose-induced $\mathrm{Ca}^{2+}$ influx and mitochondrial alterations are assumed to be important factors in dioxin-reduced GSIS [81].

Another suggestion concerning beta cell dysfunction is that TCDD exposure could affect the activity of pancreatic 
nitric oxide synthase (NOS) [82]. Although the exact function of NOS in pancreatic beta cells is still unknown, multiple studies [83] point to an important negative control of the enzyme on pancreatic beta cell function [84], although paradoxically low nitric oxide levels are noted to have positive effects [83]. As such, environmental toxicants capable of affecting NOS activity need to be tested for their potential to disrupt insulin secretion and metabolism.

Compared with TCDD, the effects of polychlorinated biphenyls (PCBs) on insulin secretion are less thoroughly studied and mechanistic information is sparser. To investigate PCB toxicity, Fischer et al. [85] exposed rat insulinoma RINm5F cells to a commercial mixture of PCBs (Aroclor 1254; Monsanto, St Louis, MO, USA) and three specific $\mathrm{PCB}$ congeners (two non-coplanar congeners [PCB-153, PCB-47] and one coplanar congener [PCB77]). The observed concentration-dependent increase in insulin secreted in cell culture medium for both Aroclor 1254 and the non-coplanar congeners suggest a secretagogue-like effect. This stimulation probably results from a mechanism that includes an increase in $\left[\mathrm{Ca}^{2+}\right]_{\mathrm{i}}$ followed by activation of a $\mathrm{Ca}^{2+} /$ calmodulin-dependent protein kinase [86] (Fig. 2).

In summary, the studies described above provide the first evidence of a possible mechanistic link between glucose metabolism disorders and low-level POP exposure. This information on the effects of PCBs and TCDD on insulin secretion clearly indicates that a more detailed and comprehensive investigation of the targeted effects of these environmental pollutants on beta cells and their involvement in type 2 diabetes development and progression is needed.

\section{Metals}

Several metals, such as cadmium, mercury and the metalloid arsenic, have been epidemiologically linked to the incidence of type 2 diabetes (reviewed in [87, 88]). The ability of metals to disrupt insulin secretion was first reported in the 1970s [89]. In this study, cadmium was suggested to have an inhibitory effect on the secretory activity of pancreatic beta cells, mediated by interference with calcium uptake. A decade later, it was suggested that at low concentrations cadmium stimulates insulin secretion, while high levels result in a significantly diminished rate of insulin release [90]. Moreover, in the Third National Health and Nutrition Examination Survey, cadmium was related with both impaired fasting glucose and diabetes [37]. In rats, chronic and subchronic cadmium exposure resulted in an accumulation of cadmium in the pancreas and reduced serum insulin levels, suggesting a possible direct toxic effect of cadmium on the pancreas $[88,91]$. In an attempt to unveil the underlying mechanism, Lei et al. [91] proposed that cadmium affects insulin transcription and translation (Fig. 2). However, a clear outline of its mode of action has not yet been published.

Arsenic seems to affect pancreatic beta cells by the induction of oxidative stress [92] and the reduction of insulin transcription and secretion [93]. The latter was deduced from altered expression of the following genes: (1) $P d x 1$ (previously known as Iufl) [93-95], a transcription factor that is essential for pancreas development, insulin production and glucose homeostasis [96]; and (2) the insulin gene [97]. Other studies reported effects on glucose uptake, induction of ROS production, interference with the activity of key antioxidant enzymes [98], apoptosis, necrosis and inflammation reactions [39, 93] (Fig. 2).

Mercury, as mercuric chloride $\left(\mathrm{HgCl}_{2}\right)$, has also been shown to target the pancreas by altering intracellular $\mathrm{Ca}^{2+}$ homeostasis in beta cells and decreasing insulin secretion from toadfish islets [99]. The association between type 2 diabetes and the Minamata disease (methylmercury [MeHg] poisoning) in Japan has further underlined the idea of the existence of mercury-induced beta cell damage [100]. The mechanism of action of mercury on pancreatic beta cells is still largely unknown. However, Chen et al. [100] examined the role of the phosphatidylinositol 3-kinase (PI3K)-Akt signalling pathway in mercury-exposed mice (in vitro and in vivo) and showed that insulin secretion is inhibited whereas oxidative stress and PI3K activation are induced. Both, PI3K and ROS are implicated in Akt signalling pathway-dependent pancreatic beta cell dysfunction.

\section{Humans at risk?}

Although the studies described above clearly indicate that some environmental pollutants are able to alter beta cell function, it has yet to be determined whether the prevailing environmental concentrations of pollutants can be a risk factor for diabetes. A first hint that the general population is exposed to concentrations that may increase diabetes prevalence is derived from epidemiological studies (Table 1). However, clear causality between human exposure to pollutants and diabetes is so far lacking. An important problem is the fact that the majority of mechanistic studies employ exposure concentrations far above the concentrations found in the human population. To allow profound risk assessment, however, more experimental data at environmentally relevant concentrations are needed. Current risk assessments predominantly use no or lowest observed adverse effect levels (NOAEL/ LOAEL), preferably derived from chronic animal studies or, if available, human exposure data to calculate acceptable daily intake doses or reference doses (RfD). Both are 
expressed in grams per kilogram per day. To extrapolate data from animal studies, uncertainty factors are used to account for, for example, species differences, length of exposure, LOAEL or NOAEL.

An overview of compound concentrations used in the cited mechanistic studies and compound RfD, if available, is presented in Table 2. At first sight the concentrations used in mechanistic (in vivo) studies are notably higher than the RfD determined by the US Environmental Protection Agency (EPA). However, low doses of bisphenol A (10$100 \mu \mathrm{g} \mathrm{kg}^{-1}$ day $^{-1}$ ) administered to mice significantly altered glucose and insulin homeostasis. These doses are in the range of the RfD of $50 \mu \mathrm{g} \mathrm{kg}^{-1}$ day $^{-1}$ defined by the US EPA [101], based on a LOAEL of $50 \mathrm{mg} \mathrm{kg}^{-1}$ day $^{-1}$ derived from studies performed in the 1980s [46]. Considering the uncertainty factors used for extrapolation of animal data to humans, doses as low as $10 \mu \mathrm{g} \mathrm{kg}^{-1} \mathrm{day}^{-1}$ affecting rodents are strong indications of human relevance. This fact, amongst others, has lead to discussions about the RfD determined by the US EPA [46, 102].

Malathion also evoked effects on insulin secretion at concentrations $\left(5,10\right.$ or $\left.20 \mathrm{mg} \mathrm{kg}^{-1} \mathrm{day}^{-1}\right)$ close to the NOAEL of $29 \mathrm{mg} \mathrm{kg}^{-1}$ day $^{-1}$ determined in a 2 year study of toxicity and carcinogenicity in rats [65, 67]. Based on this NOAEL, an acceptable daily intake of up to $0.3 \mathrm{mg} \mathrm{kg}{ }^{-1}$ day $^{-1}$ was established for humans (safety factor 100) by the Joint Food and Agriculture Organization/ World Health Organization (FAO/WHO) Meeting of Pesticide Residues (JMPR) [103]. Since malathion in doses of 10 to $20 \mathrm{mg} \mathrm{kg}^{-1}$ day $^{-1}$ fed to rats for 4 weeks altered blood glucose and insulin values, Panahi et al. [67] suggested that the previously determined NOAEL and the derived acceptable daily intake dose [103] for humans should be re-evaluated. At present, the US EPA oral RfD for malathion is set at $20 \mu \mathrm{g} \mathrm{kg}^{-1} \mathrm{day}^{-1}$ [104], and this was determined using a study of volunteers who had an oral intake of 8,16 or $24 \mathrm{mg} /$ day of malathion. In this study, the NOAEL was $16 \mathrm{mg} /$ day (equivalent to $0.27 \mathrm{mg} \mathrm{kg}^{-1} \mathrm{day}^{-1}$ for a person of $60 \mathrm{~kg}$ ). The reported RfD of the JMPR $\left(0.3 \mathrm{mg} \mathrm{kg}^{-1} \mathrm{day}^{-1}\right)$ [103], however, did not include this NOAEL value because they argued that, considering the age of the study, it was likely that the administered malathion contained toxic impurities. Although the RfD of malathion is debatable, this illustrates that the malathion concentrations producing diabetogenic effects in rat might be relevant to humans, and further research on its potential to interfere with processes involved with diabetes development and progression could give valuable information for risk assessment.

For all other compounds discussed in this review the studied concentrations are high compared with exposure levels of the general population and with concentrations that cause, for example, teratological, reproductive and developmental effects or cancer. For instance, the RfD for TCDD was very recently proposed to be set at $0.7 \mathrm{pg} \mathrm{kg}^{-1}$ day $^{-1}$ based on LOAEL $\left( \pm 20 \mathrm{pg} \mathrm{kg}^{-1}\right.$ day $\left.^{-1}\right)$ values in human studies looking at endocrine related endpoints (sperm count and thyroid-stimulated hormone concentrations), but is still under review by the US EPA [105]. In acute in vivo studies investigating effects on beta cell function, concentrations of $1-50 \mu \mathrm{g} / \mathrm{kg}$ are used [79], which are far higher than the RfD. The suggested diabetogenic potential might thus be a minor factor in the risk assessment of these compounds, because other deleterious effects are observed at much lower concentrations. However, some effects manifest themselves acutely, while others manifest themselves more chronically. The time period necessary for a compound to exert its diabetogenic properties in humans has not been investigated so far, but for the example of TCDD only acute (several hours to 10 days) in vivo effects on rabbits were monitored [79]. Because of the lack of information, it is not currently possible to draw conclusions regarding the importance of the diabetogenic effect of these compounds relative to other observed harmful effects.

Based on the findings for certain compounds, such as bisphenol A and malathion, inclusion of the diabetogenic properties might be interesting for estimations of safe acceptable daily intake or $\mathrm{RfD}$ values. Because the concentrations of compounds used in mechanistic studies are much higher than those commonly encountered in the environment, these mechanistic studies cannot provide direct information on compound toxicity in human-relevant exposure scenarios. In assessing the risk of a compound, direct extrapolation of concentration levels from simple experimental studies is not always accurate, since more complex exposure scenarios should be considered, such as long-term exposure to low concentrations, mixture effects and exposure during critical stages of development. Moreover, although the applied concentrations are higher than the exposure levels for the human population, specific effects of compounds on the pancreatic beta cell are indicative of a targeted interaction with certain regulatory pathways [102]. The pathways that are altered by, for instance, TCDD might also be triggered by other dioxin-like compounds (e.g. dioxin-like PCBs, polychlorinated dibenzofurans, polybrominated dibenzodioxins/furans). Additionally, since humans are exposed to a variety of compounds, mixtures may exert an effect even at NOAELs of individual compounds. Many compounds act by binding through receptors (oestrogenic compounds to ERs, dioxin-like compounds to the aryl hydrocarbon receptor, etc), which may lead to additive or synergistic effects of the individual compounds. 


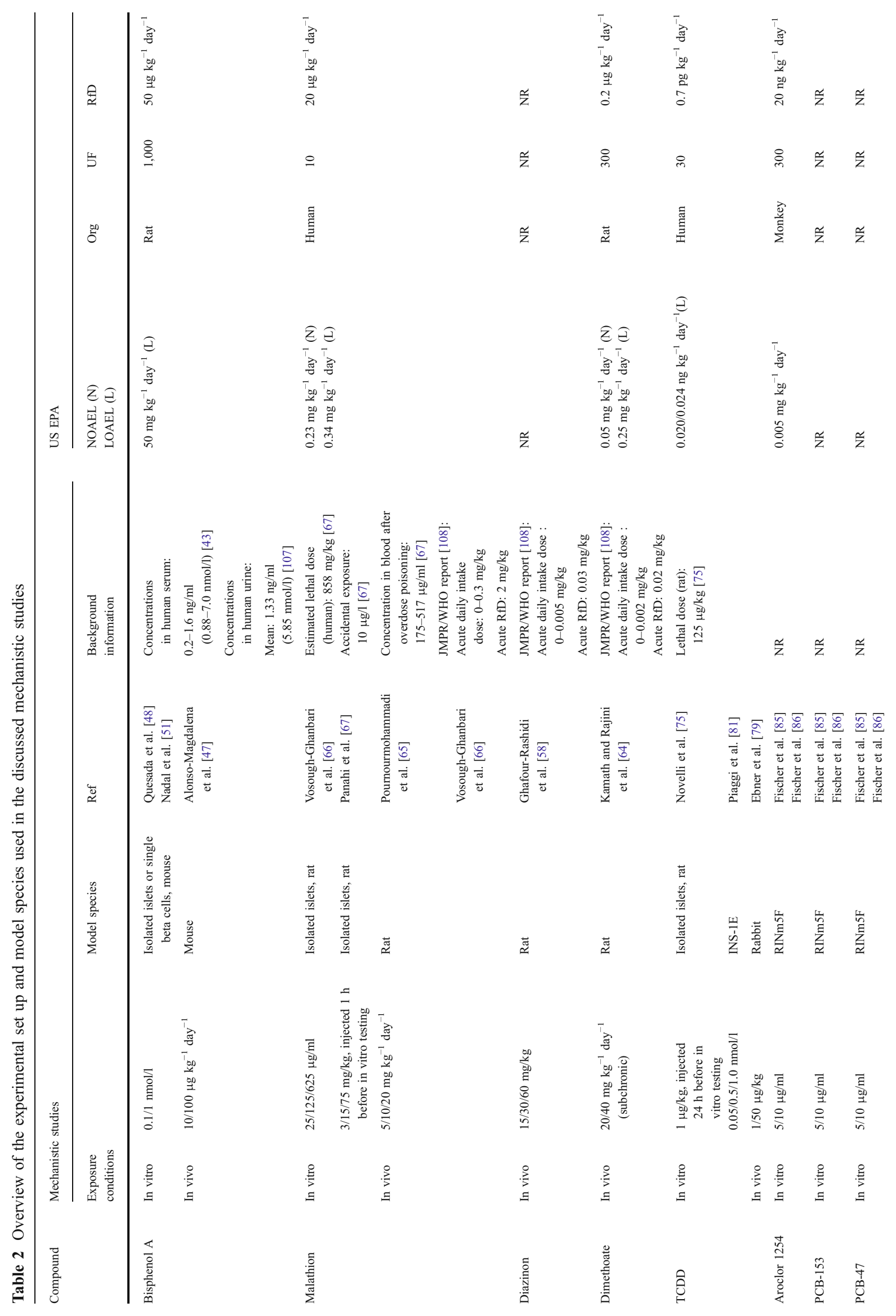




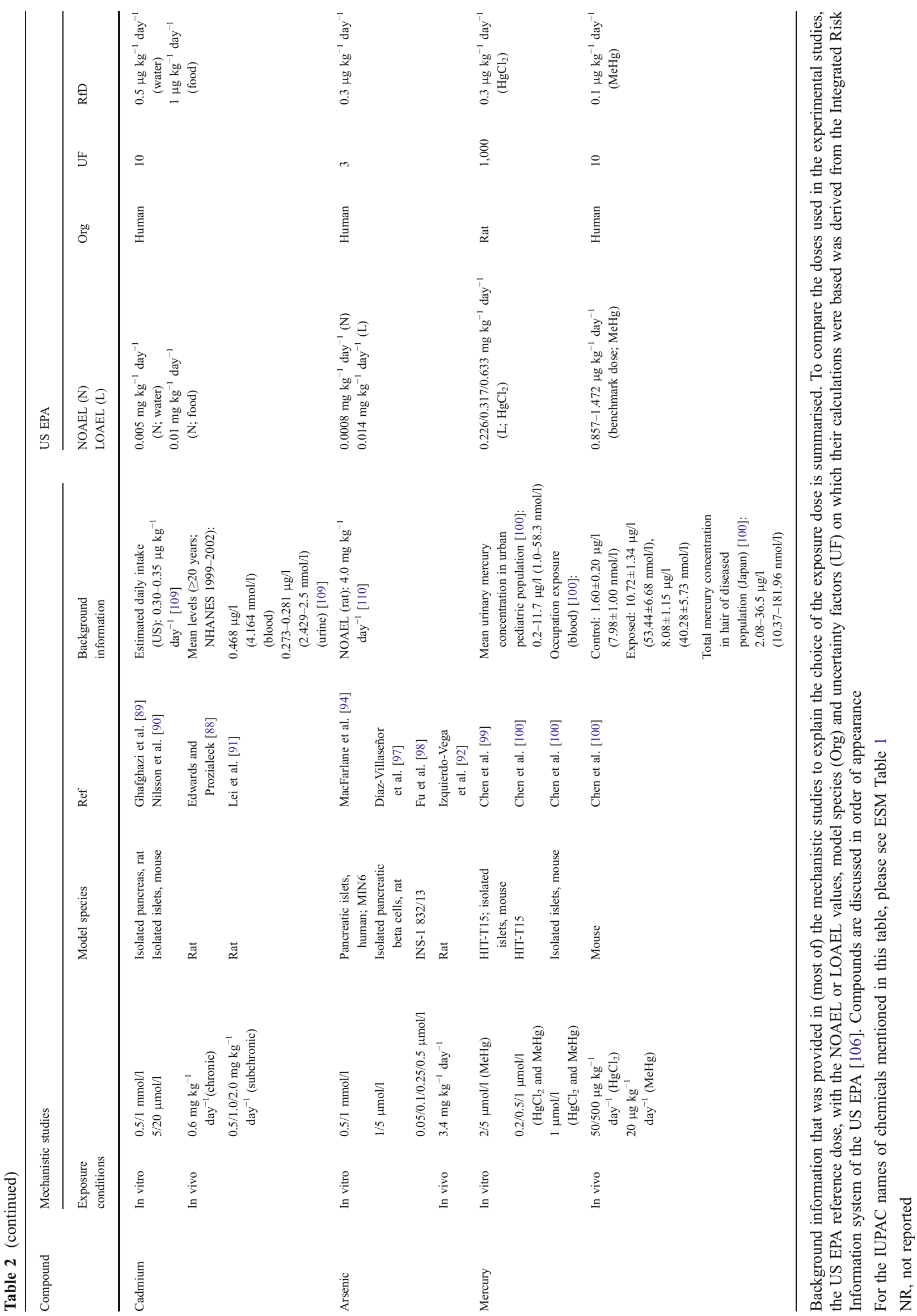




\section{Concluding remarks and future directions}

The prevalence of diabetes mellitus is currently at epidemic proportions and is a cause of great concern, not only for human health, but also because of its social and economic implications. Although genetic predisposition, obesity, diet and lack of exercise are commonly accepted causes of the development of type 2 diabetes, it is argued that these factors alone cannot fully explain the rapid rise in the prevalence of diabetes. The environment and, more specifically, environmental pollutants are mentioned as major interfering candidates. Although a large variety of compounds have been shown to be epidemiologically correlated with the occurrence of type 2 diabetes, detailed mechanistic information on how these pollutants interfere with insulin metabolism is lacking. Therefore, the present review gives an overview of the available information linking environmental pollutants with type 2 diabetes, specifically focusing on the crucial player in diabetes development, the beta cell. Although the data are sparse and fragmented, pancreatic beta cells are clearly at risk to be targeted by pollutants. Therefore, more research efforts on the interaction of compounds with beta-cell function and/or mass in animal models at human relevant concentrations are needed to further evaluate the hypothesis that environmental pollutants can be additional risk factors for diabetes development. Disentangling the pollutant's modus operandi aids to the elucidation of the underlying pathways that regulate beta cell function and hereby might reveal key regulator and signalling genes and molecules targeted by and susceptible for xenobiotic chemicals. Mechanistic studies in combination with long term in vivo exposures at low doses and multigenerational studies in animal models, will definitely ameliorate risk assessment. Simultaneously, more targeted epidemiological research should be undertaken and broadened towards the general population. Only with in-depth information on different exposure scenarios and effect levels can conclusions be made concerning human risk.

Acknowledgements T. Hectors and A. Covaci acknowledge financial support from the Scientific Research Foundation-Flanders (FWO), Belgium.

Duality of interest The authors declare that there is no duality of interest associated with this manuscript.

\section{References}

1. Zimmet P, Alberti KGMM, Shaw J (2001) Global and societal implications of the diabetes epidemic. Nature 414:782-787

2. Bhatnagar A (2009) Could dirty air cause diabetes? Circulation 119:492-494

3. Grün F, Blumberg B (2009) Endocrine disrupters as obesogens. Mol Cell Endocrinol 304:19-29
4. Longnecker MP, Daniels JL (2001) Environmental contaminants as etiologic factors for diabetes. Environ Health Perspect 109 (Suppl 6):871-876

5. Alonso-Magdalena P, Ropero AB, Soriano S, Quesada I, Nadal A (2010) Bisphenol A: a new diabetogenic factor. Hormones 9:118-126

6. Carpenter DO (2008) Environmental contaminants as risk factors for developing diabetes. Rev Environ Health 23:59-74

7. Lin Y, Sun Z (2010) Current views on type 2 diabetes. J Endocrinol 204:1-11

8. Kahn SE (2003) The relative contributions of insulin resistance and beta-cell dysfunction to the pathophysiology of type 2 diabetes. Diabetologia 46:3-19

9. Muoio DM, Newgard CB (2008) Molecular and metabolic mechanisms of insulin resistance and $\beta$-cell failure in type 2 diabetes. Nat Rev 9:193-205

10. Rutter GA (2001) Nutrient-secretion coupling in the pancreatic islet $\beta$-cell: recent advances. Mol Aspects Med 22:247-284

11. Henquin JC (2000) Triggering and amplifying pathways of regulation of insulin secretion by glucose. Diabetes 49:1751-1760

12. Jones PM, Persaud SJ (1998) Protein kinases, protein phosphorylation and the regulation of insulin secretion from pancreatic $\beta$ cells. Endocr Rev 19:429-461

13. Schuit FC, Kiekens R, Pipeleers DG (1991) Measuring the balance between insulin synthesis and insulin release. Biochem Biophys Res Commun 178:1182-1187

14. Martens GA, Pipeleers D (2009) Glucose, regulator of survival and phenotype of pancreatic beta cells. Vitam Horm 80:507-539

15. Bouwens L, Rooman I (2005) Regulation of pancreatic beta-cell mass. Physiol Rev 85:1255-1270

16. Henriksen GL, Ketchum NS, Michalek JE, Swaby JA (1997) Serum dioxin and diabetes mellitus in veterans of Operation Ranch Hand. Epidemiology 8:252-258

17. Pesatori AC, Zocchetti C, Guercilena S, Consonni D, Turrini D, Bertazzi PA (1998) Dioxin exposure and non-malignant health effects: a mortality study. Occup Environ Med 55:126-131

18. Cranmer M, Louie S, Kennedy RH, Hern PA, Fonseca VA (2000) Exposure to 2,3,7,8-tetranchlorodibenzo- $p$-dioxin (TCDD) is associated with hyperinsulinemia and insulin resistance. Toxicol Sci 56:431-436

19. Vena J, Boffetta P, Becher H et al (1998) Exposure to dioxin and nonneoplastic mortality in the expanded IARC international cohort study of phenoxy herbicide and chlorophenol production workers and sprayers. Environ Health Perspect 106(Suppl 2):645-653

20. Philibert A, Schwartz H, Mergler D (2009) An exploratory study of diabetes in a first nation community with respect to serum concentrations of $p, p^{\prime}$-DDE and PCBs and fish consumption. Int J Environ Res Public Health 6:3179-3189

21. Krämer U, Herder C, Sugiri D et al (2010) Traffic-related air pollution and incident type 2 diabetes: results from the SALIA cohort study. Environ Health Perspect 118:1273-1279

22. Uemura H, Arisawa K, Hiyoshi M et al (2008) Associations of environmental exposure to dioxins with prevalent diabetes among general inhabitants in Japan. Environ Res 108:63-68

23. Ukropec J, Radikova Z, Huckova M et al (2010) High prevalence of prediabetes and diabetes in a population exposed to high levels of an organochlorine cocktail. Diabetologia 53:899-906

24. Glynn AW, Granath F, Aune M et al (2003) Organochlorines in Swedish women: determinants of serum concentrations. Environ Health Perspect 111:349-355

25. Rignell-Hydbom A, Lidfeldt J, Kiviranta H et al (2009) Exposure to $p, p^{\prime}$-DDE: a risk factor for type 2 diabetes. PLoS ONE 4:e7503

26. Rylander L, Rignell-Hydbom A, Hagmar L (2005) A crosssectional study of the association between persistent organochlorine pollutants and diabetes. Environ Health 4:28 
27. Wang S-L, Tsai P-C, Yang C-Y, Guo YL (2008) Increased risk of diabetes and polychlorinated biphenyls and dioxins: a 24-year follow-up study of the Yucheng cohort. Diab Care 31:1574-1579

28. Codru N, Schymura MJ, Negoita S, The Akwesasne Task Force on the Environment, Rej R, Carpenter DO (2007) Diabetes in relation to serum levels of polychlorinated biphenyls and chlorinated pesticides in adult native Americans. Environ Health Perspect 115:1442-1447

29. Cox S, Niskar AS, Narayan KMV, Marcus M (2007) Prevalence of self-reported diabetes and exposure to organochlorine pesticides among Mexican Americans: Hispanic Health and Nutrition Examination Survey, 1982-1984. Environ Health Perspect 115:1747-1752

30. Everett CJ, Frithsen IL, Diaz VA, Koopman RJ, Simpson WM Jr, Mainous AG 3rd (2007) Association of a polychlorinated dibenzo- $p$-dioxin, a polychlorinated biphenyl, and DDT with diabetes in the 1999-2002 National Health and Nutrition Examination Survey. Environ Res 103:413-418

31. Lang IA, Galloway TS, Scarlett A et al (2008) Association of urinary bisphenol A concentration with medical disorders and laboratory abnormalities in adults. JAMA 300:1303-1310

32. Lee D-H, Lee I-K, Song K et al (2006) A strong dose-response relation between serum concentrations of persistent organic pollutants and diabetes: results from the National Health and Examination Survey 1999-2002. Diab Care 29:1638-1644

33. Lee D-H, Lee I-K, Steffes M, Jacobs DR Jr (2007) Extended analysis of the association between serum concentrations of persistent organic pollutants and diabetes. Diab Care 30:1596-1598

34. Lee D-H, Steffes MW, Sjödin A, Jones RS, Needham LL, Jacobs DR Jr (2010) Low dose of some persistent organic pollutants predicts type 2 diabetes: a nested case-control study. Environ Health Perspect 118:1235-1242

35. Lim J-S, Lee D-H, Jacobs DR Jr (2008) Association of brominated flame retardants with diabetes and metabolic syndrome in the U.S. population 2003-2004. Diab Care 31:1802-1807

36. Montgomery MP, Kamel F, Saldana TM, Alavanja MCR, Sandler DP (2008) Incident diabetes and pesticide exposure among licensed pesticide applicators: agricultural health study, 1993-2003. Am J Epidemiol 167:1235-1246

37. Schwartz GG, Il'yasova D, Ivanova A (2003) Urinary cadmium, impaired fasting glucose, and diabetes in the NHANES III. Diab Care 26:468-470

38. Turyk M, Anderson HA, Knobeloch L, Imm P, Persky VW (2009) Prevalence of diabetes and body burdens of polychlorinated biphenyls, polybrominated diphenyl ethers, and $p, p^{\prime}$ diphenyldichloroethene in Great Lakes sport fish consumers. Chemosphere 75:674-679

39. Navas-Acien A, Silbergeld EK, Streeter RA, Clark JM, Thomas AB, Guallar E (2006) Arsenic exposure and type 2 diabetes: a systematic review of the experimental and epidemiologic evidence. Environ Health Perspect 114:641-648

40. Heldring N, Pike A, Andersson S et al (2007) Estrogen receptors: how do they signal and what are their targets. Physiol Rev 87:905-931

41. Chen J-Q, Brown TR, Russo J (2009) Regulation of energy metabolism pathways by estrogens and estrogenic chemicals and potential implications in obesity associated with increased exposure to endocrine disruptors. Biochim Biophys Acta 1793:1128-1143

42. Nadal A, Alonso-Magdalena P, Soriano S, Quesada I, Ropero $\mathrm{AB}$ (2009) The pancreatic beta-cell as a target of estrogens and xenoestrogens: implications for blood glucose homeostasis and diabetes. Mol Cell Endocrinol 304:63-68

43. Alonso-Magdalena P, Ropero AB, Carrera MP et al (2008) Pancreatic insulin content regulation by the estrogen receptor ER $\alpha$. PLoS ONE 3:e2069
44. Nadal A, Alonso-Magdalena P, Soriano S, Ropero AB, Quesada I (2009) The role of oestrogens in the adaptation of islets to insulin resistance. J Physiol 587:5031-5037

45. Le May MC, Chu K, Hu M et al (2006) Estrogens protect pancreatic $\beta$-cells from apoptosis and prevent insulin-deficient diabetes mellitus in mice. Proc Natl Acad Sci USA 103:9232-9237

46. Nadal A, Rovira JM, Laribi O et al (1998) Rapid insulinotropic effect of $17 \beta$-estradiol via a plasma membrane receptor. FASEB J 12:1341-1348

47. Alonso-Magdalena P, Morimoto S, Ripoll C, Fuentes E, Nadal A (2006) The estrogenic effect of bisphenol A disrupts pancreatic $\beta$-cell function in vivo and induces insulin resistance. Environ Health Perspect 114:106-112

48. Quesada I, Fuentes E, Viso-León C, Soria B, Ripoll C, Nadal A (2002) Low doses of the endocrine disrupter bisphenol-A and the native hormone $17 \beta$-estradiol rapidly activate transcription factor CREB. FASEB J 16:1671-1673

49. Nadal A, Ropero AB, Fuentes E, Soria B, Ripoll C (2004) Estrogen and xenoestrogen actions on endocrine pancreas: from ion channel modulation to activation of nuclear function. Steroids 69:531-536

50. Soriano S, Ropero AB, Alonso-Magdalena P et al (2009) Rapid regulation of $\mathrm{K}_{\text {ATP }}$ channel activity by $17 \beta$-estradiol in pancreatic $\beta$-cells involves the estrogen receptor $\beta$ and the atrial natriuretic peptide receptor. Mol Endocrinol 23:1973-1982

51. Nadal A, Ropero AB, Laribi O, Maillet M, Fuentes E, Soria B (2000) Nongenomic actions of estrogens and xenoestrogens by binding at a plasma membrane receptor unrelated to estrogen receptor $\alpha$ and estrogen receptor $\beta$. Proc Natl Acad Sci USA 97:11603-11608

52. Ackermann S, Hiller S, Osswald H, Losle M, Grenz A, Hambrock A (2009) 17ß-Estradiol modulates apoptosis in pancreatic $\beta$-cells by specific involvement of the sulfonylurea receptor (SUR) isoform SUR1. J Biol Chem 284:4905-4913

53. Mårtensson UEA, Salehi SA, Windahl S et al (2009) Deletion of the $\mathrm{G}$ protein-coupled receptor 30 impairs glucose tolerance, reduces bone growth, increases blood pressure, and eliminates estradiol-stimulated insulin release in female mice. Endocrinology 150:687-698

54. Wetherill YB, Akingbemi BT, Kanno J et al (2007) In vitro molecular mechanisms of bisphenol A action. Reprod Toxicol 24:178-198

55. Richter CA, Birnbaum LS, Farabollini $F$ et al (2007) In vivo effects of bisphenol A in laboratory rodent studies. Reprod Toxicol 24:199-224

56. European Commission (2007) Commission Staff Working Document on the implementation of the "Community Strategy for Endocrine Disrupters" - a range of substances suspected of interfering with the hormone systems of humans and wildlife (COM (1999) 706), (COM (2001) 262) and (SEC (2004) 1372). SEC(2007) 1635. Commission of the European Communities, Brussels. Available from http://ec.europa.eu/environment/endocrine/documents/final report_2007.pdf. Accessed 8 February 2011

57. Welshons WV, Nagel SC, Vom Saal FS (2006) Large effects from small exposures. III. Endocrine mechanisms mediating effects of bisphenol A at levels of human exposure. Endocrinology 147:S56-S69

58. Ghafour-Rashidi Z, Dermenaki-Farahani E, Aliahmadi A et al (2007) Protection by cAMP and cGMP phosphodiesterase inhibitors of diazinon-induced hyperglycaemia and oxidative/ nitrosative stress in rat Langerhans islets cells: molecular evidence for involvement of non-cholinergic mechanisms. Pestic Biochem Physiol 87:261-270

59. Rahimi R, Abdollahi M (2007) A review on the mechanism involved in hyperglycaemia induced by organophosphorus pesticides. Pestic Biochem Physiol 88:115-121 
60. McKinlay R, Plant JA, Bell JNB, Voulvoulis N (2008) Endocrine disrupting pesticides: implications for risk assessment. Environ Int 34:168-183

61. Jeong SH, Kim BY, Kang HG, Ku HK, Cho JH (2006) Effect of chlorpyrifos-methyl on steroid and thyroid hormones in rat $\mathrm{F} 0$ - and F1-generations. Toxicology 220:189-202

62. Sahin IÇ, Onbasi K, Sahin H, Karakaya C, Ustun Y, Noyan T (2002) The prevalence of pancreatitis in organophosphate poisonings. Hum Exp Toxicol 21:175-177

63. Roeyen G, Chapelle T, Jorens P, De Beeck BO, Ysebaert D (2008) Necrotizing pancreatitis due to poisoning with organophosphate pesticides. Acta Gastroenterol Belg 71:27-29

64. Kamath V, Rajini PS (2007) Altered glucose homeostasis and oxidative impairment in pancreas of rats subjected to dimethoate intoxication. Toxicology 231:137-146

65. Pournourmohammadi S, Ostad SN, Azizi E et al (2007) Induction of insulin resistance by malathion: evidence for disrupted islets cells metabolism and mitochondrial dysfunction. Pestic Biochem Physiol 88:346-352

66. Vosough-Ghanbari S, Sayyar P, Pournourmohammadi S, Aliahmadi A, Ostad SN, Abdollahi M (2007) Stimulation of insulin and glucagon synthesis in rat Langerhans islets by malathion in vitro: evidence for mitochondrial interaction and involvement of subcellular non-cholinergic mechanisms. Pestic Biochem Physiol 89:130-136

67. Panahi P, Vosough-Ghanbari S, Pournourmohammadi S et al (2006) Stimulatory effects of malathion on the key enzymes activities of insulin secretion in Langerhans islets, glutamate dehydrogenase and glucokinase. Toxicol Mech Methods 16:161167

68. Gilon P, Henquin J-P (2001) Mechanisms and physiological significance of the cholinergic control of pancreatic $\beta$-cell function. Endocr Rev 22:565-604

69. Romero-Navarro G, Lopez-Aceves T, Rojas-Ochoa A, Fernandez Mejia C (2006) Effect of dichlorvos on hepatic and pancreatic glucokinase activity and gene expression, and on insulin mRNA levels. Life Sci 78:1015-1020

70. Gowda H, Uppal RP (1983) Effect of malathion on adrenal activity, liver glycogen and blood glucose in rats. Indian J Med Res 78:847-851

71. Stockholm Convention on persistent organic pollutants (POPs) Governments unite to step-up reduction on global DDT reliance and add nine new chemicals under international treaty. Press release, 9 May 2009. Available from: http://chm.pops.int/ Convention/Pressrelease/COP4Geneva8May2009/tabid/542/ language/en-US/Default.aspx. Accessed 11 October 2010

72. Rogan WJ, Chen A (2005) Health risks and benefits of bis(4chlorophenyl)-1,1,1-trichloroethane (DDT). Lancet 366:763-773

73. Darras VM (2008) Endocrine disrupting polyhalogenated organic pollutants interfere with thyroid hormone signaling in the developing brain. Cerebellum 7:26-37

74. Birnbaum LS (1995) Developmental effects of dioxins and related endocrine disrupting chemicals. Toxicol Lett 82:743-750

75. Novelli M, Piaggi S, De Tata V (2005) 2,3,7,8-Tetrachlorodibenzo$p$-dioxin-induced impairment of glucose-stimulated insulin secretion in isolated rat pancreatic islets. Toxicol Lett 156:307-314

76. Seefeld MD, Corbett SW, Keesey RE, Peterson RE (1984) Characterization of the wasting syndrome in rats treated with 2,3,7,8-tetrachlorodibenzo- $p$-dioxin. Toxicol Appl Pharmacol 73:311-322

77. Enan E, Liu PCC, Matsumura F (1992) 2,3,7,8-Tetrachlorodibenzo$p$-dioxin causes reduction of glucose transporting activities in the plasma membranes of adipose tissue and pancreas from the guinea pig. J Biol Chem 267:19785-19791

78. Enan E, Liu PCC, Matsumura F (1992) TCDD causes reduction in glucose uptake through glucose transporters on the plasma membranes of the guinea pig adipocyte. J Environ Sci Health B 27:495-510

79. Ebner K, Brewster DW, Matsumura F (1988) Effects of 2,3,7,8tetrachlorodibenzo- $p$-dioxin on serum insulin and glucose levels in the rabbit. J Environ Sci Health B 23:427-438

80. Matsumura F (1995) Mechanism of action of dioxin-type chemicals, pesticides, and other xenobiotics affecting nutritional indexes. Am J Clin Nutr 61(Suppl):695S-701S

81. Piaggi S, Novelli M, Martino L et al (2007) Cell death and impairment of glucose-stimulated insulin secretion induced by 2,3,7,8-tetrachlorodibenzo- $p$-dioxin (TCDD) in the $\beta$-cell line INS-1E. Toxicol Appl Pharmacol 220:333-340

82. Michalek JE, Akhtar FZ, Kiel JL (1999) Serum dioxin, insulin, fasting glucose, and sex hormone-binding globulin in veterans of Operation Ranch Hand. J Clin Endocrinol Metab 84:1540-1543

83. Lajoix AD, Reggio $H$, Chardès $T$ et al (2001) A neuronal isoform of nitric oxide synthase expressed in pancreatic $\beta$-cells controls insulin secretion. Diabetes 50:1311-1323

84. Sjöholm A (1996) Nitric oxide donor SIN-1 inhibits insulin release. Am J Physiol 271:C1098-C1102

85. Fischer LJ, Zhou H-R, Wagner MA (1996) Polychlorinated biphenyls release insulin from RINm5F cells. Life Sci 59:20412049

86. Fischer LJ, Wagner MA, Madhukar BV (1999) Potential involvement of calcium, CaM kinase II, and MAP kinases in PCB-stimulated insulin release from RINm5F cells. Toxicol Appl Pharmacol 159:194-203

87. Chen YW, Yang CY, Huang CF, Hung DZ, Leung YM, Liu SH (2009) Heavy metals and islet function and diabetes development. Islets 1:169-176

88. Edwards JR, Prozialeck WC (2009) Cadmium, diabetes and chronic kidney disease. Toxicol Appl Pharmacol 238:289-293

89. Ghafghazi T, Mennear JH (1975) The inhibitory effect of cadmium on the secretory activity of the isolated perfused rat pancreas. Toxicol Appl Pharmacol 31:134-142

90. Nilsson T, Rorsman F, Berggren PO, Hellman B (1986) Accumulation of cadmium in pancreatic $\beta$-cells is similar to that of calcium in being stimulated by both glucose and high potassium. Biochim Biophys Acta 888:270-277

91. Lei LJ, Jin TY, Zhou YF (2007) Insulin expression in rats exposed to cadmium. Biomed Environ Sci 20:295-301

92. Izquierdo-Vega JA, Soto CA, Sanchez-Peña LC, De VizcayaRuiz A, Del Razo LM (2006) Diabetogenic effects and pancreatic oxidative damage in rats subchronically exposed to arsenite. Toxicol Lett 160:135-142

93. Díaz-Villaseñor A, Burns AL, Hiriart M, Cebrián ME, OstroskyWegman P (2007) Arsenic-induced alteration in the expression of genes related to type 2 diabetes mellitus. Toxicol Appl Pharmacol 225:123-133

94. MacFarlane WM, Smith SB, James RF et al (1997) The p38/ reactivating kinase mitogen-activated protein kinase cascade mediates the activation of the transcription factor insulin upstream factor 1 and insulin gene transcription by high glucose in pancreatic beta-cells. J Biol Chem 272:20936-20944

95. Paul DS, Hernández-Zavala A, Walton FS et al (2007) Examination of the effects of arsenic on glucose homeostasis in cell culture and animal studies: development of a mouse model for arsenic-induced diabetes. Toxicol Appl Pharmacol 222:305-314

96. Stanojevic V, Habener JF, Thomas MK (2004) Pancreas duodenum homeobox-1 (PDX-1) transcriptional activation requires interactions with p300. Endocrinology 145:2918-2928

97. Díaz-Villaseñor A, Sánchez-Soto MC, Cebrián ME, OstroskyWegman P, Hiriart M (2006) Sodium arsenite impairs insulin secretion and transcription in pancreatic beta-cells. Toxicol Appl Pharmacol 214:30-34 
98. Fu J, Woods CG, Yehuda-Shnaidman E et al (2010) Low level arsenic impairs glucose-stimulated insulin secretion in pancreatic $\beta$-cells: involvement of cellular adaptive response to oxidative stress. Environ Health Perspect 118:864-870

99. Chen YW, Huang CF, Tsai KS et al (2006) Methylmercury induced pancreatic $\beta$-cell apoptosis and dysfunction. Chem Res Toxicol 19:1080-1085

100. Chen YW, Huang CF, Tsai KS et al (2006) The role of phosphoinositide 3-kinase/Akt signaling in low-dose mercuryinduced mouse pancreatic $\beta$-cell dysfunction in vitro and in vivo. Diabetes 55:1614-1624

101. US Environmental Protection Agency, Integrated Risk Information System (IRIS). Bisphenol A (CASRN 80-05-7). Available from www.epa.gov/iris/subst/0356.htm. Accessed 14 December 2010

102. vom Saal FS, Akingbemi BT, Belcher SM et al (2007) Chapel Hill bisphenol A expert panel consensus statement: integration of mechanisms, effects in animals and potential to impact human health at current levels of exposure. Reprod Toxicol 24:131-138

103. Agriculture and Consumer Protection Department of Food and Agriculture Organization of the United Nations (1998) Pesticide residues in food - 1997. Report. (FAO Plant Production and Protection Paper-145). Available from http://www.fao.org/docrep/ w8141e/w8141e0x.htm\#TopOfPage. Accessed 14 December 2010

104. US Environmental Protection Agency, Integrated Risk Information System (IRIS). Malathion (CASRN 121-75-5).
Available from www.epa.gov/IRIS/subst/0248.htm. Accessed 14 December 2010

105. US Environmental Protection Agency (U.S. EPA) (2010) EPA's reanalysis of key issues related to dioxin toxicity and response to nas comments (external review draft). US Environmental Protection Agency, Washington, EPA/600/R-10/038A

106. US Environmental Protection Agency, Integrated Risk Information System (IRIS). Available from http://www.epa.gov/iris/. Accessed 14 December 2010

107. Calafat AM, Kuklenyik Z, Reidy JA et al (2005) Urinary concentrations of bisphenol $\mathrm{A}$ and 4-nonylphenol in a human reference population. Environ Health Perspect 113:391-395

108. WHO (2009) Inventory of IPCS and other WHO pesticide evaluations and summary of toxicological evaluations performed by the Joint Meeting of Pesticide Residues (JMPR) through 2009. WHO, Geneva. Available from www.who.int/ipcs/publications/ jmpr/pesticide_inventory_edition10.pdf. Accessed 2 December 2010

109. Agency for Toxic Substances and Disease Registry (ATSDR) (2008) Toxicological profile for cadmium (Draft for public comment). US Department of Health and Human Services, Public Health Service, Atlanta

110. Holson JF, Stump DG, Clevidence KJ, Knapp JF, Farr CH (2000) Evaluation of the prenatal developmental toxicity of orally administered arsenic trioxide in rats. Food Chem Toxicol $38: 459-466$ 